\title{
IMPROVING STUDENTS SPEAKING ABILITY THROUGH REPETITION DRILL
}

\author{
Nurul Aini ${ }^{1}$, Nurul Khoyimah ${ }^{2}, \operatorname{Iman}_{\text {Santoso }}{ }^{3}$ \\ ${ }^{1}$ IKIP Siliwangi \\ ${ }^{2}$ IKIP Siliwangi \\ ${ }^{3}$ IKIP Siliwangi \\ ${ }^{1}$ nurulaini1815@gmail.com, ${ }^{2}$ nurulkhoyimah96@gmail.com, ${ }^{3}$ imansantoso515@gmail.com
}

\begin{abstract}
The objective of this research is to know how repetition drill technique improves students speaking ability of the 7thgrade students of SMP Negeri 5 Cimahi in academic year 2018/2019. The research was conducted using the Classroom Action Research method involving 36 students as the research subjects. The data was collected using an oral and written test within three cycles of research. Students mean score in the 1st cycle (September4-5, 2018) is not obtained due to reasons. Students mean score in the 2nd cycle (September11-12, 2018) is 69,10. Students mean score in the 3rd cycle (September18-19, 2018 ) is 80,56 . Students mean score in the 3 rd cycle is more preminent than the 2 nd cycle means that there is a significant improvement in students speaking ability. In conclusion, this research proved that students speaking ability could be improved through repetition drill technique.
\end{abstract}

Keywords: Speaking, Ability, Repetition Drill

\section{INTRODUCTION}

English has become an international language in the world, been established as a unifying language for all people in the world to communicate with each other. Therefore, currently, English is a language that is very important for everyone to learn. Usually, we deliver by talking, so it's essential for us to learn to speak in English.Speaking is an interactive process of constructing meaning that involves producing and receiving and processing information (Brown, 1994). Based on (Aristy, Hadiansyah, \& Apsari, 2019) defined speaking as the most important skill of all four skills because speaking is a tool for everyone to communicate between one people to another. Without speaking, we can't make a good relationship with other people, besides that if we have a problem that can't we solve by yourself so we can share about that and get help from other. We can have a good connection with many people from anywhere through speaking.

In the other side, according to Henry Guntur Tarigan (2008) explains that speaking is a language skill that develops in the life of a child that is only preceded by listening skills, and at that time the ability to speak or say is learned.To communicate orally in English, the students should be able to use several speaking skills to express what they mean in functional oral text and very simple short monolog. However, speaking is considered as one of difficult skill in learning English. Many students have learned English for a long time since the elementary school moreover some students have learned English from kindergarten, but they still get difficulty in practicing speaking to communicate.

\section{Ability}


Ability is the potential that exists in the form of ability, skill, rigidity we try with ourselves (Yusdi, 2011). Ability is more on the effectiveness of the person in doing all kinds of work, which means that ability is the basis of someone doing a job effectively and certainly efficiently. Besides that, ability needs to complete our work or to control the things that we want to do in a job. English language skills of students must be improved so that students can speak English well and correctly.

Freeman in Risnadedi (2001: 56-57) stated that speaking ability more complex and difficult than people assume, and speaking study like study other cases in study of language, naturalize many case to language teachers.

\section{Repetition drill}

Furthermore, at its simplest, drilling means listening to the model, provided by the teacher, or a tape or another student in the classroom, and repeating what is heard. It is a repetition drill. In a repetition drill, the teacher says the model (words and phrases) and the students repeat it. (Tice, 2004). Usually, people can do something that they didn't know before by looking to the model or pattern how to do it.

As students, they can start to learn English by looking to the model or repeat what the model do/ say. Repetition drill is an excellent method to help students to learn English because people can say a word by hearing a word before. The teacher can say a sentence again and again with a clear voice, so the students can listen to well the sentence. Repetition of the penalty make the students popular with the words in the sentence; this may be used for the students to get the new vocabulary and will be useful for pronunciation class.

\section{METHOD}

In this article, the researcher uses the Classroom Action Research method, where the researcher pays more attention to the teaching and learning process. The researcher planned activity that hopefully, can overcome the problem that appears in the classroom. Action research is a research where the teacher also as a researcher, tries to make a better teaching-learning process as (Kunandar, 2008) defines that Action Research is a type of research activity carried out by educators (teachers) that are useful for improving the quality of education in the classroom. Based on Arikunto (2007), there are some steps in the classroom action research.

The concept used in this classroom action research is cyclical process adapted from Lewin in (Parmawati, 2010) so the Classroom Action Research procedures are as follow:(1) Planning: The researcher made a plan to find out the problem and prepares everything needed the research such as lesson plan, and instruments to collect data. (2) Acting: The researcher researches in the classroom where the problem found. The researcher teaches the prepared lesson. The researcher uses repetition drill to encourage the students to speak English. (3) Observing: The researcher collected the data and information to put in the field note. (4) Reflecting: The result of observation then used to do the reflection to know whether the action of teaching is valid or not. The researcher and collaborator discuss to find the weakness of the response has been done and will be used to determine what should be done in the next cycles.

The technique of data collecting applied in this research is performance test is used for assessing students performance based on the scoring table of a rating scale of speaking, and the observation technique.Moreover, tools of data collecting that will be applied in this research 
are (1) Oral test: The students do the oral test with two scoring criteria, fluency, and pronunciation. (2) Observation checklist table: The researcher applies observation to see the students reaction or responses to the teaching and learning activities in the classroom.(3) Field note: Written all students activities in the classroom from step to step, during teaching-learning process, to know students behavior in the class, and (4) Students task: Task is a useful tool to see the achievement of students comprehension about the material.

The students must reach the standard score or Kriteria Ketuntasan Minimum (KKM). The minimum standard score is 75 from 100. Scoring assessment or rubrics are scoring guides containing the criteria used to evaluate the student's performance adapted from New Jersey World Languages Curriculum Framework as follow:

Table 1. Fluency score

\begin{tabular}{ccc}
\hline Category & Descriptors & Point \\
\hline Smooth delivery & $\begin{array}{c}\text { Has natural pausing, around } \\
1 \text { to 5 pausing of } \\
\text { thinking }\end{array}$ & 4 \\
\hline Fairly smooth & $\begin{array}{c}\text { The number of breaks } \\
\text { around } 6 \text { to } 10\end{array}$ & 3 \\
\hline Unnatural pauses & $\begin{array}{c}\text { The number of breaks } \\
\text { around } 11 \text { to } 5\end{array}$ & 2 \\
\hline Halting; hesitant; long & The number of breaks more \\
than 15 & 1 \\
\hline gaps & & \\
\hline
\end{tabular}

Table 2. Pronunciation score

\begin{tabular}{|c|c|c|}
\hline Category & Descriptors & Point \\
\hline $\begin{array}{c}\text { Accurate throughout, near } \\
\text { native }\end{array}$ & $\begin{array}{l}\text { Pronunciation errors not } \\
\text { more than 5, excellent and } \\
\text { acceptable pronounciation }\end{array}$ & 4 \\
\hline $\begin{array}{c}\text { Understandable, with very } \\
\text { view } \\
\text { errors }\end{array}$ & $\begin{array}{c}\text { Pronunciation }{ }^{\text {ee }} \text { faultsaround } \\
6 \text { to } 10 . \text { Good enough } \\
\text { pronunciation }\end{array}$ & 3 \\
\hline $\begin{array}{l}\text { Some mistakes but still } \\
\text { understandable }\end{array}$ & $\begin{array}{l}\text { Some pronunciation }{ }^{\text {ee }} \text { errors } \\
\text { around to } 11 \text { to } 15 . \\
\text { Pronunciation still } \\
\text { understandable with much } \\
\text { mother tongue influence }\end{array}$ & 2 \\
\hline
\end{tabular}




$\begin{array}{cc}\begin{array}{c}\text { Poor pronounciation, very } \\ \text { anglicized }\end{array} & \begin{array}{c}\text { Many pronounciation's } \\ \text { errors very anglicized }\end{array}\end{array}$

To measure students ${ }^{\text {ee }}$ individual score :

$X=\frac{F S+P S}{2}$

Fluency Score $(\mathrm{FS}) \quad=$ total point $\mathrm{x} 25$

Pronounciation Score $(\mathrm{PS}) \quad=$ total point $\mathrm{x} 25$

From the mean score and statistical analysis, it can be judged whether the students speaking skill improves or not.

Table 3. Score Qualification

\begin{tabular}{cc}
\hline Mean Score & Specification \\
\hline $77-100$ & Excellent \\
\hline $60-76$ & Good \\
\hline $50-59$ & Average \\
\hline $0-49$ & Poor \\
\hline
\end{tabular}

\section{RESULTS AND DISCUSSION}

\section{Results}

\section{The First Cycle}

The first cycle was conducted on $4^{\text {thto }} 5^{\text {th }}$ of September 2018.In the first meeting, the teacher started the teaching-learning process by giving brainstorming before explaining about the materials. The researcher asked them some question dealing with the topic. The researcher also helped the students in understanding the materials that were used as the learning topics by the researcher for the students to guide their pronunciation and helping them to understand the difficult words in it. The researcher drilled the students in the material. The researcher drilled the students for several time in the order they could pronounce it correctly.

In the second meeting, the researcher taught about preposition, besides that the researcher explained the purpose and structure of to the students. Explained the part of the proposition in more detailed with the detail example.

\section{The Second Cycle}

The second cycle was conducted on $11^{\text {thand }} 12^{\text {th}}$ of September 2018, and in this cycle, the students were seen to be enthusiastically involved in the teaching-learning process. The second cycle consisted of two meetings. The first meeting was for repeating the teaching and learning 
process about the last meeting before. At the second meeting was for assessing student's performance after doing the drilling.

The researcher gave brainstorming to the students before starting the lesson by showing the picture in the book and asking some questions related to the topic in the picture. After the researcher told the learning objective of the meeting, the researcher then calls the students one by one to asked some question to tell the preposition or place of the things in the picture and the students have to answer the question orally. Besides that, the researcher then gives a written task about the topic to tell the places of many things in the classroom (5 things) by using preposition words. After that, the researcher checked the answer about the preposition words in the student's task.

Most students did a good performance. Finally, the teacher got the student's score from their performance, and the result is as follows:

Table4. Students Score in Second Cycle

\begin{tabular}{|c|c|c|c|}
\hline No & Student Fluency & Pronunciation & Total Score \\
\hline 1. & 2 & 3 & 62,5 \\
\hline 2. & 2 & 3 & 62,5 \\
\hline 3. & 3 & 3 & 75 \\
\hline 4. & 2 & 2 & 50 \\
\hline 5. & 3 & 3 & 75 \\
\hline 6. & 3 & 3 & 75 \\
\hline 7. & 2 & 3 & 62,5 \\
\hline 8. & 3 & 3 & 75 \\
\hline 9. & 3 & 4 & 87,5 \\
\hline 10. & 2 & 3 & 62,5 \\
\hline 11. & 3 & 3 & 75 \\
\hline 12. & 3 & 3 & 75 \\
\hline 13. & 2 & 3 & 62,5 \\
\hline 14. & 3 & 3 & 75 \\
\hline 15 & 3 & 3 & 75 \\
\hline 16. & 2 & 2 & 50 \\
\hline
\end{tabular}




\begin{tabular}{|c|c|c|c|}
\hline 17. & 3 & 3 & 75 \\
\hline 18. & 2 & 3 & 62,5 \\
\hline 19. & 2 & 2 & 50 \\
\hline 20. & 3 & 3 & 75 \\
\hline 21. & 2 & 3 & 62,5 \\
\hline 22. & 3 & 3 & 75 \\
\hline 23. & 3 & 3 & 75 \\
\hline 24. & 2 & 3 & 62,5 \\
\hline 25. & 3 & 4 & 87,5 \\
\hline 26. & 3 & 3 & 75 \\
\hline 27. & 3 & 3 & 75 \\
\hline 28. & 2 & 2 & 50 \\
\hline 29. & 3 & 3 & 75 \\
\hline 30. & 3 & 3 & 75 \\
\hline 31. & 2 & 3 & 62,5 \\
\hline 32. & 2 & 3 & 62,5 \\
\hline 33. & 2 & 2 & 50 \\
\hline 34. & 3 & 4 & $\mathbf{8 7 , 5}$ \\
\hline 35. & 2 & 3 & 62,5 \\
\hline 36. & 3 & 4 & $\mathbf{8 7 , 5}$ \\
\hline
\end{tabular}

To measure students ${ }^{\text {ee }}$ individual score :

$\mathrm{X}=\frac{\text { FS }+ \text { PS }}{2} \quad \begin{array}{ll}\text { Note: } \\ \text { Fluency Score (FS) } \\ \text { Pronounciation Score (PS) }\end{array}$

To measure students ${ }^{\text {ee }}$ mean score:
$\mathrm{M}=\frac{\Sigma \mathrm{X}}{\mathrm{N}}$
Note : $\mathrm{M}=$ the students ${ }^{\text {ee }}$ mean score
$\Sigma \mathrm{X}=$ the sum of students ${ }^{\text {ee }}$ score
$\mathrm{N}=$ the number of students being observed 


$$
\begin{aligned}
\mathrm{M} & =\frac{\Sigma \mathrm{X}}{\mathrm{N}} \\
& =\frac{2.487,5}{36}=69,10
\end{aligned}
$$

From the students mean score above, we can classify that the students are in a good category. From the table above, we can see that there are 20 students passed from the standard score. It can be said that the plan that the researcher made work well. So, we can see the class percentage based on KKM below:

$$
\mathrm{CP}=\frac{\mathrm{GM}}{\mathrm{N}} \times 100 \% \quad \text { Note: } \begin{aligned}
& \mathrm{CP}=\text { Class Percentage } \\
& \mathrm{GM}=\text { the Number of students get } 70 \text { and above } \\
& \mathrm{N}=\text { the number of a student being observed }
\end{aligned}
$$

$\mathrm{CP}=\frac{20}{36} \times 100 \%=\mathbf{5 5 , 5 6 \%}$

Based on the data above, the plans that had been made was unsatisfactory. The researcher hoped that the number of students pass would increase in the next meeting.

\section{The Third Cycle}

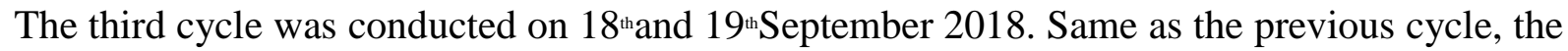
first meeting was for the teaching-learning process, and the second meeting was for assessing students performance. At the first meeting (September, 18) the researcher did brainstorming to the students before starting the lesson by showing the different picture and asking the same question related to the picture. The students were also asked to really keep their attention to all of the activity in drilling. The researcher asked the students about the difficulties that they got in the process of teaching and learning and gave them motivation, for example, asking them to be ready and should not delay their turn to perform like the previous meeting.

The student's performance was held on September 19. Before the test was started, the researcher motivated the students to perform well and better than before and reminded about two aspects that would be scored from their performance. Each student then took his/ her turn to perform in front of the class. In this cycle, most of the students performed much better than the previous performance. The number of students who had a problem with fluency and pronunciation was decreased.

Table 5. Students' Score in the ThirdCycle

\begin{tabular}{llll}
\hline No & Student Fluency & Pronunciation & Total Score \\
\hline 1. & 3 & 3 & 75 \\
\hline 2. & 3 & 4 & 87,5 \\
\hline 3. & 3 & 3 & 75 \\
\hline
\end{tabular}




\begin{tabular}{|c|c|c|c|}
\hline 4. & 2 & 3 & 62,5 \\
\hline 5. & 3 & 4 & 87,5 \\
\hline 6. & 3 & 4 & 87,5 \\
\hline 7. & 3 & 3 & 75 \\
\hline 8. & 3 & 3 & 75 \\
\hline 9. & 3 & 4 & 87,5 \\
\hline 10. & 3 & 4 & 87,5 \\
\hline 11. & 3 & 4 & 87,5 \\
\hline 12. & 3 & 4 & 87,5 \\
\hline 13. & 3 & 3 & 75 \\
\hline 14. & 3 & 4 & 87,5 \\
\hline 15 & 3 & 3 & 75 \\
\hline 16. & 3 & 4 & 87,5 \\
\hline 17. & 3 & 3 & 75 \\
\hline 18. & 2 & 3 & 62,5 \\
\hline 19. & 2 & 3 & 62,5 \\
\hline 20. & 3 & 4 & 87,5 \\
\hline 21. & 3 & 4 & 87,5 \\
\hline 22. & 3 & 4 & 87,5 \\
\hline 23. & 3 & 4 & 87,5 \\
\hline 24. & 2 & 3 & 62,5 \\
\hline 25. & 3 & 3 & 75 \\
\hline 26. & 2 & 3 & 62,5 \\
\hline 27. & 3 & 4 & 87,5 \\
\hline 28. & 3 & 3 & 75 \\
\hline 29. & 3 & 4 & 87,5 \\
\hline
\end{tabular}




\begin{tabular}{llll}
\hline 30. & 3 & 3 & 75 \\
\hline 31. & 3 & 4 & 87,5 \\
\hline 32. & 2 & 3 & 62,5 \\
\hline 33. & 3 & 62,5 \\
\hline 34. & 3 & 4 & 87,5 \\
\hline 35. & 3 & 3 & 75 \\
\hline 36. & 3 & 4 & 87,5 \\
\hline & & TOTAL SCORE $(\Sigma X)$ & 2.875 \\
\hline
\end{tabular}

Students mean score in Cycle $3=\mathbf{7 9 , 8 6}$

There were 10,76 points increasing from the students speaking ability. Based on the table, there were 29 students passed from the standard score. It can be said that the plan worked well. The class percentage based on KKM as follows:

$\mathrm{CP}=\frac{\mathrm{GM}}{\mathrm{N}} \times 100 \%$
$\mathrm{CP}=\frac{29}{36} \times 100 \%=\mathbf{8 0 , 5 6 \%}$

Based on the data above, it can be said that the plan worked well and prosverous.

\section{Discussion}

This research used classroom action research. It was conducted in three cycles. From the research finding above, it could be seen that the students speaking ability improved from the second cycle. At the first cycle, there was no test score could be taken, because, on the first cycle the researcher was doing the learning process about the material. Because of that, the researcher did some changes in the plans from the next cycle.

In the second cycle, the students are seen to be enthusiastic about involved in the teachinglearning process, although there were some students still made an error in pronouncing some words in drilling. Then, the researcher drilled the words several time until they declared it well. So that in the performance session there were 20 students got the score 70 or above. It means that there were about $55,56 \%$ of students in the class achieved the minimum standards score. While in the last cycle, the students keep interested in the teaching-learning process, and they were repeated after the recorder seriously. So that the error in pronunciation could be minimized and most of the student's performance was getting much better than the previous one. There were 29 students got 70 or above, or it can be said that the percentage of the well-performed students increased became $80,56 \%$. 
Students showed their significant progress in the third cycle. They were brave and had the confidence to come in front of the class. Repetition drill made students more interested in the lesson.

\section{CONCLUSION}

Students speaking ability improved by using repetition drill from the cycle to cycle. This was proved by the result of the mean score and the result of the observation. At the first cycle, the writer did not get the students to score. The second cycle was 68,75 , and the last cycle was 80,08 . In the first cycle, the writer did not get the students to score because there were some problems that happened in this cycle. The problems were an unclear explanation, the length of the text for teaching material, the speed of the audio record, and others. The writer and collaborator planned to make the next cycle. Through the second cycle, students competences step by step were increased. Students speaking result was excellent. There were 18 students passed. But there were only $56,25 \%$ students could get score 70 or above as the minimum standard score (KKM). Next, the writer and collaborator continued with the last cycle. In the last cycle, students showedsignificant progress to the result. It gave the writer a substantial that the speaking ability improved. Students fluency and pronounciation aspect on the seventh grade students of SMP Negeri 5 Cimahi in academic year 2018/2019.

\section{ACKNOWLEDGMENTS}

Alhamdulillahi rabil 'alamin, highest gratitude to Allah SWT for blessing, love, opportunity, health, and mercy to complete this article entitled "Improving Students Speaking Ability Through Repetition Drill." Is submitted as the final requirement in accomplishing undergraduate degree at IKIP Siliwangi. In this valuable chance, the researcher intended to express his gratitude and appreciation to our lecturer Mr. Iman Santoso that have been guide us to arranging this journal and thanks a lot of people has provided motivation, advice, and support for us.This journal is far from perfect, but it is expected that it will be useful not only for the researcher but also for the readers.

\section{REFERENCES}

Arikunto, S. (2007). Penelitian Tindakan Kelas (Ptk) Untuk Guru, Kepala Sekolah, Pengawas, Dan Penilai. Universitas Negeri Yogyakarta Diakses Tanggal, 6.

Aristy, I., Hadiansyah, R., \& Apsari, Y. (2019). Using Three Step-Interview To Improve Student's Speaking Ability. Project (Professional Journal Of English Education), 2(2), 175-180.

Brown, H. D., Kosslyn, S. M., Breiter, H. C., Baer, L., \& Jenike, M. A. (1994). Can Patients With Obsessive-Compulsive Disorder Discriminate Between Percepts And Mental Images? A Signal Detection Analysis. Journal Of Abnormal Psychology, 103(3), 445.

Definition Of Speaking Skill. (2013). Retrieved From Http://Www.Zakymedia.Com/2013/06/Definition-Of-Speaking-Skill.Html

Media, T. (N.D.). Pengertian Berbicara Menurut Para Ahli.

Parmawati, A. Using Magic Sentences Technique To Improve Students'vocabulary (Classroom Action Research In The First Semester Students Of Ikip Siliwangi Bandung).

Student, I. (2017). No Title. Retrieved From Https://Www.Indonesiastudents.Com/PengertianPenelitian-Tindakan-Kelas-Menurut-Para-Ahli/

Yusdi, M. (2011). Pengertian Kemampuan. Tersedia: Http://Milmanyusdi. Blogspot. Com/2011/07/Pengertian-Kemampuan. Html [18 Desember 2012]. 